\title{
MANAJEMEN KUALITAS \\ PADA SUPPLY CHAIN KEMASAN GELAS \\ DI PT. IGLAS (PERSERO) SURABAYA
}

\author{
Elly Ismiyah \\ Program Studi Teknik Industri \\ Universitas Muhammadiyah Gresik \\ Email : ismi_elly@yahoo.com
}

\begin{abstract}
Abstrak
$\mathrm{K}$ ualitas adalah salah satu faktor yang menentukan keberhasilan suatu industri di tengah persaingan. PT.Iglas (Persero) merupakan salah satu produsen kemasan gelas perlu memandang kualitas tidak hanya dari sisi produksi tetapi juga dari proses-proses lain dalam supply chainnya karena problem-problem kualitas tidak hanya terjadi pada proses produksi saja tetapi juga pada proses-proses lain dalam supply chain. Dengan konsep Supply Chain Quality Management (SCQM), masalah kualitas yang ada pada supply chain kemasan gelas di PT.Iglas (Persero) Surabaya akan diteliti dan dianalisa. Pada setiap stage supply chain diidentifikasi masalah kualitas yang terjadi, dari jenis cacat yang ditemukan kemudian dibuat pareto diagram untuk mengetahui cacat kritisnya dan cause effect diagram untuk mengidentifikasi penyebabnya. Selain itu penelitian juga bertujuan untuk mengetahui praktek manajemen kualitas perusahaan melalui framework yang telah ditentukan. Hasil dari penelitian ini selain cacat-cacat yang terjadi pada stages supply chain kemasan gelas, juga menyajikan upaya-upaya perusahaan maupun bersama anggota supply chain lain untuk meningkatkan kualitas kemasan gelas, posisi perusahaan dalam tingkatan praktek manajemen kualitas dan usulan perbaikan untuk mengurangi jumlah cacat.
\end{abstract}

Kata Kunci : Kualitas, SCQM, Tingkatan manajemen kualitas.

\section{PENDAHULUAN \\ Latar Belakang}

Salah satu faktor yang sangat menentukan apakah suatu industri dapat bertahan di tengah persaingan tersebut adalah kualitas dari produk yang dihasilkan oleh industri tersebut. Selama ini masalah-masalah kualitas yang terjadi di perusahaan banyak dikaitkan dari sisi produksi saja, baik dari kesalahan metode saat memproduksi atau kesalahan yang disebabkan oleh kelalaian sumber daya manusianya dalam memproduksi produk yang dihasilkan. Di sisi lain problem-problem kualitas tidak hanya terjadi pada proses produksi saja tetapi juga pada proses-proses lain dalam supply chain. Proses-proses tersebut antara lain produksi bahan baku oleh supplier, delivery bahan baku dari supplier ke pabrik, penyimpanan bahan baku di pabrik, penyimpanan produk jadi di gudang, sampai pada pengiriman produk ke pelanggan. Pada semua proses di atas dimungkinkan terjadi cacat atau problem kualitas.

Kemasan gelas merupakan salah satu produk yang sangat dibutuhkan oleh berbagai industri mulai dari industri minuman ringan, minuman beralkohol, farmasi, jar dan saus sampai dengan kosmetik. Dengan konsep supply chain quality management peneliti berupaya untuk mengangkat masalah quality management pada perusahaan kemasan gelas yaitu di PT. Iglas (Persero) Surabaya dimana tinjauan kualitas akan dilihat pada beberapa proses supply chain antara lain pada pengiriman pasokan bahan baku dari supplier ke Pabrik, proses produksi (terdiri dari penyiapan dan pencampuran bahan baku, peleburan dan reaksi kimia, pembentukan botol, pendinginan dan pelabelan), pengemasan, penyimpanan produk jadi pada gudang dan pengiriman produk ke pelanggan. Peneliti juga akan mengevaluasi upayaupaya perusahaan dengan partner-partner supply chain dalam melakukan joint improvement dalam hal kualitas serta mengevaluasi posisi PT.Iglas dalam hal manajemen kualitas dalam kaitannya dengan perlunya melihat aspek-aspek kualitas dari perspektif supply chain. 


\section{Tujuan Penelitian}

Tujuan yang hendak dicapai adalah :

1. Memetakan proses-proses fisik supply chain kemasan gelas.

2. Mengevaluasi permasalahan-permasalahan kualitas yang terjadi pada tiap-tiap proses yang diamati.

3. Mengevaluasi sebab-sebab yang dominan dari permasalahan-permasalahan kualitas tersebut.

4. Mengevaluasi upaya-upaya perusahaan dalam melihat kualitas sebagai tanggung jawab bersama beberapa elemen pada supply chain (baik internal maupun eksternal organisasi).

5. Mengevaluasi dimana posisi perusahaan dalam penerapan manajemen kualitas.

\section{Manfaat Penelitian}

Manfaat yang dapat diberikan antara lain:

1. Perusahaan dapat mengetahui faktor-faktor apa saja yang menyebabkan terjadinya cacat pada produk yang dihasilkan tidak hanya dari proses produksi tetapi juga dari proses lain dalam supply chain gelas.

2. Perusahaan dapat mengetahui posisi dan orientasi manajemen kualitas yang diterapkan selama ini.

3. Memberikan usulan perbaikan sehingga perusahaan dapat melakukan perbaikan secara berkesinambungan.

\section{Ruang Lingkup Penelitian}

Proses yang diamati terdiri dari proses dalam salah satu suppliernya, penerimaan bahan baku dari supplier, produksi, pengemasan, penyimpanan, pengiriman produk ke konsumen serta penerimaan produk oleh salah satu konsumennya.

\section{Tinjauan Pustaka}

\section{Konsep Kualitas dan Manajemen Kualitas}

Kualitas adalah totalitas dari fitur dan karakteristik dari sebuah produk atau jasa yang dihubungkan dengan kemampuannya untuk memuaskan pengguna atau kebutuhan (Besterfield $d k k, 1995)$. Pengendalian kualitas adalah aktivitas keteknikan dan manajemen, yang dengan aktivitas tersebut dapat diukur ciri-ciri kualitas dari produk yang ada, membandingkan dengan spesifikasi atau persyaratan, dan mengambil tindakan penyehatan yang sesuai apabila ada perbedaan antara penampilan yang sebenarnya dengan yang standar (Montgomery, 1995) Menurut Gitlow, dkk, 1995, tipe dari kualitas adalah :

\section{Quality of Design}

Berfokus pada menentukan karakteristik kualitas produk yang cocok dengan kebutuhan pasar / dengan harga yang diberikan, sehingga kualitas ini berfokus pada orientasi konsumen

2. Quality of Conformance

Suatu penawaran dimana perusahaan dan supplier dapat memproduksi barang dengan derajat keseragaman dan ketergantungan yang dapat diprediksi pada biaya yang sesuai dengan karakteristik kualitas yang ditentukan pada studi kualitas design.

\section{Quality of Performance}

Berfokus pada menentukan bagaimana karakteristik kuailtas ditentukan pada studi kualitas design dan diimprove serta diinovasi pada studi kesesuaian kualitas dapat ditunjukan di pasar.

Tabel 1. Dimensi dari kualitas (Besterfield dkk, 1995)

\begin{tabular}{|l|l|}
\hline \multicolumn{1}{|c|}{ Dimensi } & \multicolumn{1}{|c|}{ Arti dan contoh } \\
\hline Performance & $\begin{array}{l}\text { Karakteristik utama produk, contoh: } \\
\text { ketajaman gambar }\end{array}$ \\
\hline Features & $\begin{array}{l}\text { Karakteristik kedua, fitur tambahan, } \\
\text { contoh: remote kontrol }\end{array}$ \\
\hline Conformance & $\begin{array}{l}\text { Bertemunya antara spesifikasi } \\
\text { standar industri dengan hasil kerja } \\
\text { manusia }\end{array}$ \\
\hline Reliability & $\begin{array}{l}\text { Ronsistensi performansi sepanjang } \\
\text { waktu, lifetime suatu produk }\end{array}$ \\
\hline Durability & Usefullife, termasuk perawatan \\
\hline Service & $\begin{array}{l}\text { Resolusi dari problem atau } \\
\text { komplain }\end{array}$ \\
\hline Response & Kuman to human interface \\
\hline Aesthetics & $\begin{array}{l}\text { Karakteristik yang berhubungan } \\
\text { dengan perasaan }\end{array}$ \\
\hline Reputation & $\begin{array}{l}\text { Past performance dan sesuatu yang } \\
\text { tidak dapat diraba seperti ranking }\end{array}$ \\
\hline
\end{tabular}

Kualitas yang baik akan dihasilkan oleh proses yang terkendali, di dalam pengendalian kualitas terdapat 7 alat pengendali kualitas yang disebut sebagai seven tools yang digunakan untuk mengidentifikasi perbaikan yang mungkin dapat dilakukan, yaitu:

\section{1. $\underline{\text { Histogram }}$}

Histogram mempunyai bentuk seperti diagram batang yang dapat digunakan untuk mengetahui harga rata-rata atau central tendency dari nilai data yang terkumpul, harga maksimum dan minimum data, range data, besar penyimpangan atau dispersi terhadap harga rata-rata, bentuk distribusi data yang terkumpul. 


\section{Check Sheet}

Adalah alat bantu untuk memudahkan proses pengumpulan data berupa lembaran dengan tabeltabel untuk pengisian data.

\section{Diagram Pareto}

Merupakan suatu tool yang bersifat deskriptif belaka, tujuannya adalah mempermudah pihak perbaikan kualitas untuk menentukan jenis-jenis kesalahan manakah yang harus menjadi prioritas utama perbaikan dalam upaya untuk peningkatan kualitas.

\section{Defect Contentration Diagram}

Merupakan salah satu alat untuk memastikan lokasi defect yang dapat memberikan informasi tentang penyebab potensial defect. Konsep utama adalah menunjukkan secara langsung letak cacat yang terjadi pada spesimen dengan memberi tanda khusus pada gambar spesimen.

\section{Cause-Effect Diagram}

Diagram ini digunakan untuk menganalisa dan menemukan faktor-faktor yang berpengaruh secara signifikan dalam menentukan karakteristik kualitas output kerja, mencari penyebab-penyebab yang sesungguhnya dari suatu masalah. Menurut Gaspersz (2002) dalam diagram sebab akibat, setiap akar penyebab masalah dikategorikan berdasarkan prinsip 7M, yaitu:

- Manpower (tenaga kerja)

- Machines (mesin-mesin)

- Methods (metode kerja)

- Materials (bahan baku dan bahan penolong)

- Motivation (motivasi)

- Media (lingkungan dan waktu kerja)

- Money (dukungan finansial yang diberikan)

6. Scatter Diagram (Diagram Pencar)

Diagram ini digunakan untuk menemukan atau melihat korelasi dari suatu faktor penyebab yang berkesinambungan terhadap faktor lain. Dari penyebaran scater dapat dianalisa hubungan faktor sebab akibat.

\section{Control Chart (Peta Kontrol)}

Peta kontrol pada dasarnya merupakan alat analisa yang dibuat mengikuti metoda statistik dimana data yang berkaitan dengan kualitas produk atau proses diplot dalam sebuah peta dengan batas kontrol atas (BKA) dan batas kontrol bawah (BKB).
Komponen prinsip dari manajemen kualitas adalah : (Robinson and Maholtra, 2004)

- Customer focus and orientation

- Strategic planning and leadership

- Continous improvement and learning

- Empowerment and teamwork

- Human resource focus

- Management structure

- Quality tools

- Supplier support

\section{Konsep Supply Chain}

Kata Supply Chain memang sudah tidak asing lagi, banyak topik yang membicarakannya karena pada kenyataannya Supply Chain memang dibutuhkan untuk mencapai suatu tujuan dalam rangka memenuhi kebutuhan konsumen. Pengertian Supply Chain adalah semua bagian yang terkait baik secara langsung maupun tidak langsung dalam memenuhi keinginan konsumen (Chopra dan Meindl, 2004). Sedangkan Supply Chain Management (SCM) sendiri adalah Manajemen aliran di antara stage pada supply chain untuk memaksimalkan total keuntungan supply chain (Chopra dan Meindl, 2004).

Komponen prinsip dari Supply Chain Management adalah : (Robinson dan Maholtra, 2004)

- Transportatoin Logistic - Best Practice

- Marketing

- Supply Base Integration

- Organizational

- Continous Improvement and Program

- Relationship Partnership

- Strategic Management

\section{Konsep Supply Chain Quality Management}

Dalam industri yang sangat kompetitif saat ini pandangan tentang konsep kualitas secara tradisional yaitu memandang kualitas hanya dari segi produksi saja memang perlu dikaji ulang karena dalam kenyataan yang ternjadi secara nyata di lapangan cacat/defect dapat terjadi dimanapun termasuk di setiap stage dalam supply chain. Dalam suatu perusahaan misalnya cacat dapat terjadi pada saat bahan baku dikirim dari supplier, proses penyimpanan produkjadipadagudang penyimpanan atau dapat juga terjadi pada saat pengiriman produk jadi pada konsumen. Definisi Supply Chain Quality Management adalah koordinasi dan integrasi secara formal dari proses bisnis termasuk di dalamnya semua partner organisasi dalam supply 
chain untuk mengukur, menganalisa dan secara berkelanjutan meningkatkan kualitas produk, jasa dan proses yang bertujuan menciptakan nilai dan mencapai kepuasan dari konsumen intermediate dan konsumen akhir. (Ross, 1997).

Menurut Mehra dkk, 2001, sedikitnya terdapat 45 elemen yang mempengaruhi Total Quality Management (TQM) dikategorikan menjadi lima (5) kunci area yaitu :
1. Fokus dari SDM

2. Struktur Manajemen

3. Alat Pengendalian Kualitas

Menurut Robinson dan Maholtra, 2004, saat ini fokus organisasi sudah menuju pada semua anggota channel supply chain khususnya organisasi ekstrernal, evolusi dan fokus dari organisasi dapat ditunjukkan pada tabel 2.

Tabel 2. Evolusi dan Fokus SCQM

(Robinson dan Maholtra,2004)

\begin{tabular}{|c|c|c|c|c|c|}
\hline Tahun & $1920-1960$ & $1960-1980$ & $1980-1990$ & $1990-2004$ & 2004 s/d sekarang \\
\hline Program & $\begin{array}{l}\text { - Acceptance } \\
\text { Sampling } \\
\text { - Control Chart } \\
\text { - Statistical } \\
\text { Quality Control } \\
\text { - Inspection }\end{array}$ & $\begin{array}{l}\text { - Zero } \\
\text { Defect } \\
\text { - Problem } \\
\text { Solving } \\
\text { - Quality } \\
\text { Circle } \\
\text { - SPC\&DoE }\end{array}$ & $\begin{array}{l}\text { - } \text { TQM } \\
\text { - } \text { ISO } \\
\text { - } 9001 \\
\text { - } \text { Baldrige } \\
\text { - Award } \\
\text { - Six Sigma }\end{array}$ & Supply Chain Manag. & $\begin{array}{l}\text { Supply Chain } \\
\text { Quality Manag. }\end{array}$ \\
\hline Fokus & $\begin{array}{l}\text { Organisasi } \\
\text { Internal }\end{array}$ & $\begin{array}{l}\text { Organisasi } \\
\text { Internal }\end{array}$ & $\begin{array}{l}\text { - Supply base } \\
\text { - Organisasi } \\
\text { - Customer } \\
\text { Expectation }\end{array}$ & $\begin{array}{l}\text { Semua anggota supply } \\
\text { chain utamanya } \\
\text { Internal Organisasi }\end{array}$ & $\begin{array}{l}\text { Semua anggota } \\
\text { supply chain } \\
\text { utamanya Eksternal } \\
\text { Organisasi }\end{array}$ \\
\hline
\end{tabular}

\section{METODE}

\section{Pengumpulan Data}

Metode pengumpulan data yang digunakan dalam penelitian ini adalah dengan cara :

- Mengambil/mencatat data-data yang ada

- Pengamatan langsung di lapangan

- Wawancara dengan staff atau karyawan yang berhubungan dengan bidang yang diteliti.

- Pengisian kuisioner untuk mengetahui penerapan manajemen kualitas.

Pengisian kuisioner tidak dilakukan oleh semua pegawai tetapi hanya pegawai yang memiliki jabatan yang dirasa dapat mewakili untuk mngetahui kondisi perusahaan dalam penerapan manajemen kualitas. Dalam hal ini pengisian kuisioner untuk mengetahui penerapan manajemen kualitas dilakukan oleh jabatan Wakil Komite Quality Management System and ISO, Kepala Satuan Pengawas Intern dan Manajer Product Desain.

Data yang diperoleh dari keempat metode pengambilan data yang dilakukan selanjutnya dibuatkan peta proses, pareto diagram dan cause and effect diagram, diidentifikasi penjabaran program-program perusahaan dalam hal kualitas dan koordinasi perusahaan dengan anggota supply chain. Dari hasil tersebut di atas dapat dilakukan analisa kondisi perusahaan dalam hal kualitas saat ini untuk kemudian diberikan usulan perbaikan guna mengurangi jumlah cacat. Aktivitas-aktivitas Peneltian secara jelas dapat dilihat pada gambar 1 .

\section{Kerangka Evaluasi Manajemen Kualitas}

Untuk mengevaluasi manajemen kualitas yang diterapkan perusahaan diperlukan suatu kerangka (framework) yang berfungsi sebagai landasan dalam menilai posisi perusahaan dalam hal manajemen kualitas, dari beberapa sumber yang ada dapat diketahui bahwa manajemen kualitas yang diterapkan di suatu perusahaan bisa berada pada tingkatan yang berbeda-beda. Tingkatan ini bisa dibedakan berdasarkan beberapa hal antara lain bagaimana fokus manajemen kualitas di perusahaan tersebut, perhatian manajemen terhadap manajemen kualitas, tinggi rendahnya keterlibatan semua pihak dalam organisasi dalam menciptakan sistem kualitas, serta keterlibatan pihak-pihak di luar organisasi untuk secara bersama-sama mendukung upaya-upaya peningkatan kualitas. Tabel 3. menyajikan empat fokus manajemen kualitas yaitu: 


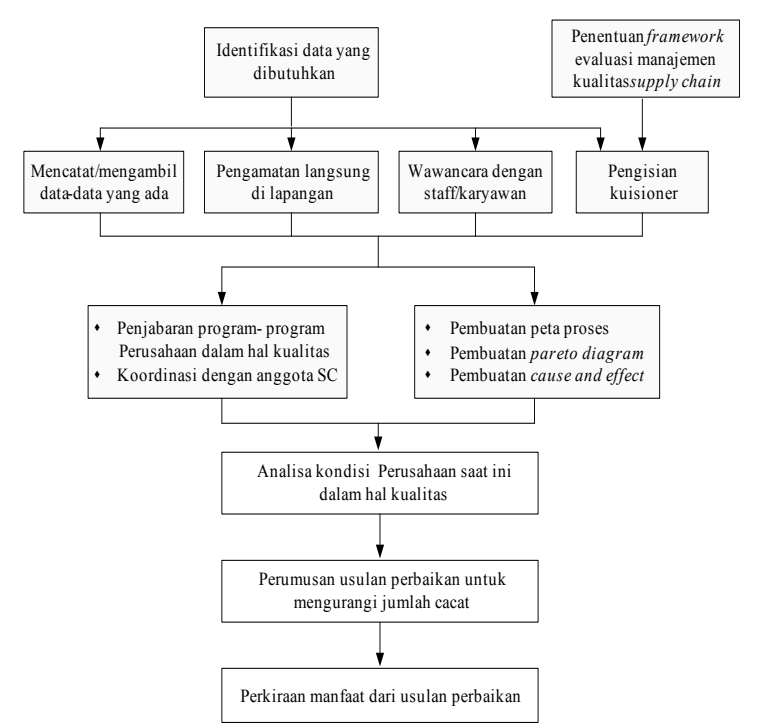

Gambar 1. Aktivitas-aktivitas Penelitian

1. Reaktif, kualitas hanya dilihat sebagai kualitas produk itu sendiri. Pada level ini, pendekatan manajemen kualitas biasanya reaktif terhadap permasalahan yang muncul. Kualitas dilihat sebagai kesesuaian dengan spesifikasi teknis. Produk yang cacat biasanya dibuang atau dirework, tapi upaya-upaya untuk mencegah tingkat reject yang tinggi bukan merupakan fokus yang utama. Kegiatan pengendalian kualitas terfokus pada bagian produksi atau operasi karena memang kualitas dipersepsikan sebagai kualitas produk.

2. Preventif, kualitas diciptakan dengan melakukan pengendalian proses. Fokusnya tidak lagi melakukan inspeksi terhadap produk yang sudah selesai dibuat atau sudah datang dari supplier, tetapi lebih fundamental, yakni mencegah terjadinya kerusakan (reject) dengan melakukan pengendalian proses (process control). Walaupun fokusnya masih pada area produksi / operasi saja, pendekatan ini secara substansial dianggap lebih baik dibandingkan pendekatan pertama tadi karena upaya pencegahan akan bisa mengurangi biaya-biaya kualitas secara signifikan. Pendekatan ini juga menggunakan alat-alat analisis seperti 7 tools.

3. Strategis, kualitas dilihat sebagai outcome dari upaya organisasi secara keseluruhan. Pada tingkatan ini, kualitas bukan hanya merupakan output dari bagian produksi dan operasi, namun dianggap menjadi output dari semua fungsi yang ada dalam organisasi. Tema cross-functional team menjadi penting dalam pendekatan ini. Kualitas tidak lagi dianggap semata-mata hal teknis, namun dianggap merupakan bagian dari strategi manajemen. Dukungan dalam implementasi program-program kualitas langsung datang dari tingkat manajemen puncak dan semua lini dan fungsi terlibat dalam program-program kualitas. Model manajemen kualitas seperti Total Quality Management (TQM), ISO 9000, dan beberapa program quality award ada pada tingkatan ini.

4. Kolaboratif, melibatkan pihak di luar organisasi untuk menciptakan kualitas lintas perusahaan sebagai upaya untuk menciptakan pelayanan yang tinggi bagi pelanggan akhir. Pendekatan supply chain management yang berakar pada kolaborasi, integrasi informasi, dan kepercayaan menjadi pilar-pilar dalam supply chain quality management ini. Beberapa hal yang perlu terjadi pada tingkatan ini adalah adanya upaya secara bersama-sama dari beberapa perusahaan yang ada dalam rangkaian supply chain untuk melaksanakan programprogram peningkatan kualitas. Termasuk di antaranya adalah keterlibatan supplier dalam merancang produk baru sehingga tercipta rancangan yang berkualitas (quality of design), upaya perusahaan untuk melakukan pembinaan supplier sehingga ada jaminan bahwa material atau komponen yang dikirim memiliki kualitas yang baik yang pada akhirnya akan mengurangi perlunya melakukan incoming inspection.

Tabel 3. Tingkatan Praktek Manajemen Kualitas serta Ciri-cirinya

\begin{tabular}{|c|c|c|c|}
\hline $\begin{array}{c}\text { Reactive, product- } \\
\text { focused }\end{array}$ & $\begin{array}{c}\text { Preventive, process- } \\
\text { oriented }\end{array}$ & $\begin{array}{c}\text { Organization focus, } \\
\text { company wide } \\
\text { involvement }\end{array}$ & \begin{tabular}{c} 
Supply-chain approach \\
\hline Reactive
\end{tabular} \\
\hline
\end{tabular}




\begin{tabular}{|c|c|}
\hline $\begin{array}{l}\text { Incoming inspection } \\
\text { Conformance to } \\
\text { technical specification }\end{array}$ & $\begin{array}{l}\text { Process control, } \\
\text { conformance to process } \\
\text { parameters (Quality is built } \\
\text { into the process) }\end{array}$ \\
\hline $\begin{array}{l}\text { Quality is at hand of } \\
\text { the inspectors }\end{array}$ & $\begin{array}{l}\text { Problem solving, cause } \\
\text { effect analysis }\end{array}$ \\
\hline Operations only & $\begin{array}{l}\text { Pareto analysis } \\
\text { Other } 7 \text { tools } \\
\text { Operations only }\end{array}$ \\
\hline
\end{tabular}

\section{HASIL DAN PEMBAHASAN \\ Masalah-masalah Kualitas}

Dalam proses pembuatan kemasan gelas mulai dari bahan baku sampai menjadi produk akhir tidak selalu lancar, terdapat beberapa masalah kualitas yang timbul di beberapa tahapnya.

\section{Kualitas pengiriman bahan baku dari Supplier}

Bagian laboratorium kimia akan memeriksa setiap kiriman yang datang. Bahan baku yang tidak memenuhi spesifikasi yang telah dibuat oleh PT.Iglas akan ditolak. Kebanyakan dari bahan baku yang ditolak adalah bahan baku yang berasal dari supplier lokal, terutama untuk bahan baku beling, hal ini dimungkinkan kurangnya pengetahuan supplier tentang spesifikasi yang dibuat oleh perusahaan.

Sedangkan untuk supplier dari luar negeri seperti Soda Ash dapat dikatakan tidak pernah terjadi penolakan pengiriman bahan baku karena mereka sudah memiliki sertifikasi bahwa produk yang dihasilkan sesuai dengan standar. Tabel 4 . menyajikan nama supllier yang pengirimannya pernah ditolak dan frekuensi penolakannya.

Dari hasil kunjungan yang dilakukan pada salah satu supplier yang pengirimannya pernah ditolak yaitu CV.Gunung Beling didapatkan informasi bahwa selama ini pengiriman bahan baku yang tidak memenuhi spesifikasi yang ditetapkan dalam surat pesanan oleh PT.Iglas tidak ditolak atau dikembalikan melainkan diberlakukan sistem potongan. Apabila dari hasil pemeriksaan oleh tim incoming inspection (laboratorium kimia) menunjukkan adanya campuran beling yang melebihi batas minimum yang ditetapkan oleh PT.Iglas maka jumlah bahan baku yang

\begin{tabular}{l|l|}
$\begin{array}{l}\text { Conformance to system } \\
\text { and procedure }\end{array}$ & $\begin{array}{l}\text { Joint initiatives with other } \\
\text { SC members }\end{array}$ \\
$\begin{array}{l}\text { Cross functional, not only } \\
\text { operations }\end{array}$ & $\begin{array}{l}\text { Collaborative, rather than } \\
\text { adversarial approach }\end{array}$ \\
Employee involvement & Trust \\
$\begin{array}{l}\text { Top management } \\
\text { commitment, quality is } \\
\text { managerial }\end{array}$ & $\begin{array}{l}\text { Information sharing and } \\
\text { visibility }\end{array}$ \\
$\begin{array}{l}\text { Quality is a strategic } \\
\text { competitiveness factor }\end{array}$ & $\begin{array}{l}\text { Commitment and supports } \\
\text { from top managements of } \\
\text { the collaborating parties }\end{array}$ \\
Quality is a supply chain \\
wide competitive weapon
\end{tabular}

dikirim tersebut akan dipotong pembayarannya, sehingga supplier hanya menerima pembayaran atas jumlah kiriman setelah dikurangi potongan. Namun alasan jumlah potongan yang diberlakukan tidak diinformasikan kepada supplier sehingga supplier tidak mengetahui secara pasti apa yang menyebabkan kirimannya dipotong dengan jumlah tersebut. Namun demikian, supplier merasa tidak dirugikan terhadap adanya potongan tersebut, supplier menerima berapapun potongan yang dikenakan tanpa mngetahui penyebab pastinya.

\section{Penyimpanan Bahan Baku}

Bahan baku yang telah diterima kemudian akan disimpan pada silo-silo tersendiri berdasarkan macamnya. Problem yang pernah terjadi adalah bahan baku tertentu menjadi basah akibat cuaca yang tidak mendukung, tetapi hal ini jarang terjadi karena turnover bahan baku yang sangat cepat.

Tabel 4. Supplier dan frekuensi penolakan

\begin{tabular}{|l|c|}
\hline \multicolumn{1}{|c|}{ Supplier } & Frekuensi Ditolak \\
\hline CV. Sumber Beling & 24 \\
\hline CV. Gunung Beling & 9 \\
\hline CV. Waringin Kurung & 8 \\
\hline PD. Beling Abadi & 5 \\
\hline CV. Artha Sarana Graha & 3 \\
\hline CV. Wredatama & 2 \\
\hline CV. Bangun Artha & 1 \\
\hline Koperasi pegawai PT.IGLAS & 1 \\
\hline PT. Kartika Chandra & 1 \\
\hline PT. Wira Swasta Sejahtera & 1 \\
\hline
\end{tabular}

\section{Proses Forming}

Proses forming merupakan proses inti dari 
pembuatan kemasan gelas, banyak jenis cacat yang timbul pada proses ini. Bagian Pengawasan Mutu Produksi bertanggung jawab terhadap pelaksanaan kegiatan pemeriksaan dan pengawasan mutu produksi sesuai metode dan prosedur pengendalian mutu yang telah ditetapkan agar dapat memenuhi permintaan pelanggan. Bagian ini mengklasifikasikan jenis cacat menjadi empat (4) yaitu :

\section{a. Critical Defect/Cacat Kritis}

Suatu cacat botol yang membahayakan orang lain/pengguna dan dapat mengakibatkan kegagalan dalam proses di pelanggan.

b. Major Defect/Cacat Fungsional

Suatu cacat botol yang dapat mengakibatkan kegagalan dalam proses di pelanggan.

c. Minor Defect/Cacat Rupa

Suatu cacat botol yang secara nampak/rupa kurang baik sehingga dapat mempengaruhi penampilan tidak bagus.

d. Dimensional Defect/Cacat Dimensi

Suatu cacat botol dimana botol memiliki dimensi yang tidak sesuai dengan spesifikasi yang ditetapkan.

Bagian pengawasan mutu menerapkan sistem sampling dalam memeriksa cacat yang ada yaitu dengan menggunakan Military Standart 105 D, (tabelnya ditunjukkan pada lampiran 4) dengan ketentuan sebagai berikut:

- Critical Defect AQL $0.065 \%$

- Major Defect AQL $1 \%$

- Minor Defect AQL $6.5 \%$ (dengan pelanggan tertentu menggunakan persyaratan AQL $4 \%$

Acceptance Quality Level (AQL) adalah suatu batasan kualitas yang dapat diterima antara pihak produsen dan pelanggan atau dengan kata lain menunjukkan tingkat kualitas yang terendah bagi proses produsen yang akan dipandang dapat diterima sebagai rata-rata proses.

Tujuan random sampling adalah untuk memberikan keputusan secara statistik bahwa produk yang akan diserahkan ke pelanggan memenuhi spesifikasi berdasarkan hasil pemeriksaan sampling.

Dari hasil pengamatan selama bulan juninovember 2005 diketahui beberapa jenis cacat dan jumlahnya. Untuk mengetahui jenis cacat yang kritis pada masing-masing klasifikasi jenis cacat maka dibuat pareto diagram dengan menggunakan software Minitab 14. Gambar 2 contoh pareto diagram yang menunjukkan kategori critical defect mesin SB1.1 dimana cacat kritisnya adalah Over Press yang memberikan kontribusi sebesar $70.2 \%$ dari total cacat untuk kategori ini.

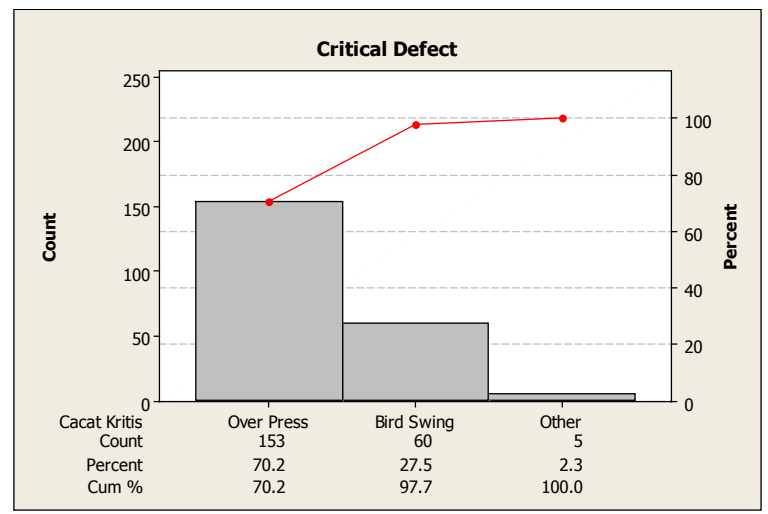

Gb. 2 Diagram Pareto Critical Defect Mesin SB1.1

Untuk lebih jelas tabel 5 menyajikan jenis cacat kritis untuk masing-masing kategori cacat yang ada pada mesin SB1.1

Tabel 5. Cacat kritis untuk Mesin SB 1.1

\begin{tabular}{|c|c|c|c|}
\hline $\begin{array}{c}\text { Klasifikasi } \\
\text { Cacat }\end{array}$ & $\begin{array}{c}\text { Jenis Cacat } \\
\text { kritis } \\
\end{array}$ & kontribusi & Total \\
\hline Cacat Kritis & Over Press & $70,2 \%$ & $70,2 \%$ \\
\hline \multirow{4}{*}{ Cacat Major } & Crack shoulder & $24,4 \%$ & \multirow{4}{*}{$77,8 \%$} \\
\hline & Crack On Ring & $21,0 \%$ & \\
\hline & $\begin{array}{l}\text { Crack Under } \\
\text { Ring }\end{array}$ & $18,8 \%$ & \\
\hline & Pinched Neck & $13,6 \%$ & \\
\hline \multirow{5}{*}{ Cacat Minor } & Crizzle & $25,0 \%$ & \multirow{5}{*}{$67,0 \%$} \\
\hline & Cold Mould & $17,0 \%$ & \\
\hline & Loading Mark & $11,0 \%$ & \\
\hline & Wrinkle & $8,0 \%$ & \\
\hline & Bad Glass & $6,0 \%$ & \\
\hline $\begin{array}{c}\text { Cacat } \\
\text { Dimensional }\end{array}$ & $\begin{array}{l}\text { Ring Body No } \\
\text { Go }\end{array}$ & $54,1 \%$ & $54,1 \%$ \\
\hline
\end{tabular}

Sedangkan tabel 6 dibawah ini menyajikan jenis cacat kritis untuk masing-masing kategori cacat yang ada pada mesin SB1.2

Tabel 6 Cacat kritis untuk Mesin SB 1.2

\begin{tabular}{|c|l|c|c|}
\hline $\begin{array}{c}\text { Klasifikasi } \\
\text { Cacat }\end{array}$ & \multicolumn{1}{|c|}{$\begin{array}{c}\text { Jenis Cacat } \\
\text { Kritis }\end{array}$} & Kontribusi & Total \\
\hline \hline Critical Defect & Over Press & $78,8 \%$ & \multirow{2}{*}{$78,8 \%$} \\
\hline \multirow{4}{*}{ Major Defect } & Crack Shoulder & $28,0 \%$ & \multirow{2}{*}{$60,0 \%$} \\
\cline { 2 - 3 } & $\begin{array}{l}\text { Crack Under } \\
\text { Ring }\end{array}$ & $15,0 \%$ & \multirow{2}{*}{$60,0 \%$} \\
\cline { 2 - 3 } & Crack Body (P) & $11,0 \%$ & \multirow{2}{*}{$60 \%$} \\
\cline { 2 - 3 } & Crack Bottom & $7,0 \%$ & \multirow{2}{*}{$85,4 \%$} \\
\hline \multirow{3}{*}{$\begin{array}{c}\text { Minor Defect } \\
\text { Dimensional } \\
\text { Defect }\end{array}$} & Crizzle & $19,0 \%$ & \\
\cline { 2 - 3 } & Cold Mould & $14,0 \%$ & \\
\cline { 2 - 3 } & Wrinkle & $85,4 \%$ & \\
\hline
\end{tabular}




\section{Penjelasan beberapa jenis cacat} Cacat Over Press

Kelebihan gelas menonjol di bibir botol, cacat ini digolongkan cacat kritis karena dapat membahayakan orang lain/pengguna dan dapat mengakibatkan kegagalan dalam proses di pelanggan.

Jenis Cacat Major, yang dapat mengakibatkan kegagalan dalam proses di pelanggan, antara lain

Cacat Crack Shoulder: Adanya retak yang terdapat pada bagian shoulder atau pundak botol.

Cacat Crack On Ring : Adanya retak yang terdapat pada bagian ring botol.

Cacat Crack Under Ring : Adanya retak yang terdapat pada bagian bawah ring botol.

Cacat Crack Body (P) : Adanya retak yang terdapat pada bagian body botol yang disebabkan adanya gesekan/kontak dengan metal pendorong.

Jenis Cacat Minor, yang hanya mempengaruhi penampilan fisik atau rupa botol

Cacat Crizzle : Adanya goresan horizontal dalam jumlah kecil pada dinding botol

Cacat Cold Mould : Adanya gelembung pada body botol dan kasar.

Cacat Loading Mark : Adanya goresan vertical maupun horizontal pada dinding botol.

Cacat Wrinkle: Adanya retak di bagian sambungan botol tetapi tidak seluruh sambungan, hanya pada beberapa bagian saja.

Cacat Bad Glass : Ketebalan gelas yang tidak merata.

\section{Cacat Ring Body No Go}

Cacat Ring Body No Go adalah cacat dimana ring body dari botol tersebut tidak dapat melewati alat pengukur diameter body atau dengan kata lain, tidak sesuai dengan spesifikasi yang ditentukan oleh pelanggan. Salah satu penyebabnya adalah cetakan yang memang sudah membesar karena sering dipoles.

\section{Cacat Concentricity}

Cacat Concentricity adalah cacat dimana botol yang dihasilkan bengkok atau tidak tegak lurus.

Selanjutnya untuk masing-masing jenis cacat dicari faktor yang dapat menyebabkan terjadinya cacat tersebut dengan cause effect diagram. Gambar 3 dan 4 merupakan gambar cause effect diagram untuk jenis cacat over press dan crack shoulder

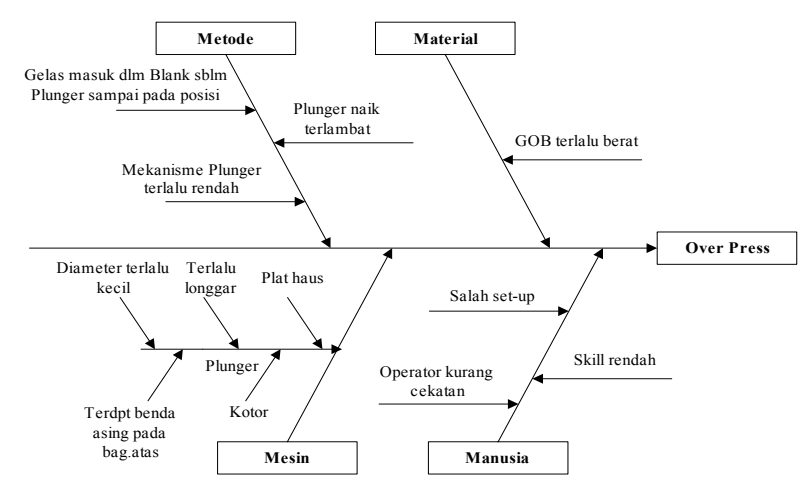

Gb 3. Cause Effect Diagram Jenis Cacat Over Press

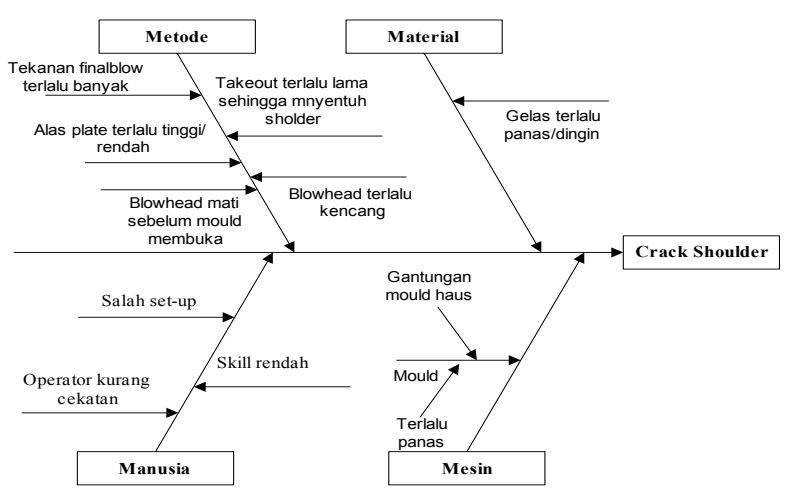

Gb 4. Cause Effect Diagram Jenis Cacat Crack Shoulder

\section{Proses Applied Ceramic Labelling (ACL)}

Proses Applied Ceramic Labelling atau yang biasa disingkat dengan proses ACL merupakan proses lanjut yang tidak semua botol hasil produksi dari mesin forming mengalami proses ini, tergantung dari pesanan. Masalah kualitas tidak hanya terjadi pada proses forming, pada proses ACL pun terjadi masalah kualitas yang diklasifikasikan menjadi tiga penyebab utama, yaitu karena mesin ACL atau Lehr, karena cat atau screen dan karena kualitas botol itu sendiri. Kualitas botol merupakan salah satu penyebab terjadinya masalah kualitas pada proses ACL, hal ini disebabkan botol cacat yang lolos dari pengawasan bagian Sortir dan tidak tersampling oleh bagian pengawasan mutu.

Dari hasil pengumpulan data yang dilakukan untuk periode produksi 6 bulan mulai Juni hingga November 2005 dan dari pembuatan diagram pareto diperoleh tabel 7 dan tabel 8

Tabel 7. Cacat Kritis untuk Mesin ACL SB.1

\begin{tabular}{|c|c|c|c|}
\hline $\begin{array}{c}\text { Klasifikasi } \\
\text { Cacat }\end{array}$ & $\begin{array}{c}\text { Jenis Cacat } \\
\text { Kritis }\end{array}$ & Kontribusi & Total \\
\hline $\begin{array}{c}\text { Karena Mesin/ } \\
\text { Lehr }\end{array}$ & Meleset & $65.5 \%$ & $65.5 \%$ \\
\hline \multirow{3}{*}{$\begin{array}{c}\text { Karena Cat/ } \\
\text { Screen }\end{array}$} & Noda Cat & $38.7 \%$ & \multirow{3}{*}{$84.4 \%$} \\
\hline & Cat Blobor & $25.6 \%$ & \\
\hline & $\begin{array}{l}\text { Cat Berlubang/ } \\
\text { Gripis }\end{array}$ & $20.1 \%$ & \\
\hline \multirow{2}{*}{ Karena Botol } & Loading Mark & $30.2 \%$ & \multirow{2}{*}{$60.3 \%$} \\
\hline & Crizzle & $30.1 \%$ & \\
\hline
\end{tabular}


Tabel 8. Cacat Kritis untuk Mesin ACL SB.2

\begin{tabular}{|c|c|c|c|}
\hline $\begin{array}{c}\text { Klasifikasi } \\
\text { Cacat }\end{array}$ & Jenis Cacat Kritis & Kontribusi & Total \\
\hline $\begin{array}{c}\text { Karena Mesin/ } \\
\text { Lehr }\end{array}$ & Meleset & $89.4 \%$ & $89.4 \%$ \\
\hline \multirow{4}{*}{$\begin{array}{c}\text { Karena Cat/ } \\
\text { Screen }\end{array}$} & Noda Cat & $27.4 \%$ & \multirow{4}{*}{$97.6 \%$} \\
\hline & $\begin{array}{l}\text { Huruf Hilang/ } \\
\text { Putus }\end{array}$ & $23.6 \%$ & \\
\hline & $\begin{array}{l}\text { Cat Berlubang/ } \\
\text { Gripis }\end{array}$ & $23.6 \%$ & \\
\hline & Cat Blobor & $23.0 \%$ & \\
\hline \multirow{2}{*}{ Karena Botol } & Loading mark & $41.5 \%$ & \multirow{2}{*}{$61.8 \%$} \\
\hline & Crizzle & $20.3 \%$ & \\
\hline
\end{tabular}

Penyebab dari semua jenis cacat yang terjadi pada proses ACL tersebut ditunjukkan pada tabel 9.

\section{Proses Pengemasan}

Tidak ada record atau catatan mengenai jumlah kesalahan yang terjadi saat pengemasan. Namun dari data komplain yang diterima perusahaan selama periode januari - September 2005, terdapat komplain dari Customer yang menyatakan bahwa kiriman yang datang berada dalam kondisi pembungkus plastik kendor dan ikatan yang kurang kencang. Selain itu ada juga komplain yang menyatakan bahwa botol diterima dalam keadaan roboh. Masalah yang dapat terjadi pada tahap ini terutama untuk kemasan yang terbuat dari bahan plastik yang mengalami proses shrink atau pemanasan dengan nyala api dengan tujuan agar plastik tersebut dapat menopang botol agar tidak jatuh. Selama proses shrink terjadi kemungkinan plastik menjadi lubang karena nyala api yang diberikan berlebihan demikian pula jika nyala api yang diberikan kurang dapat menyebabkan plastik masih kendor.

Tabel 9. Penyebab cacat pada ACL

\begin{tabular}{|c|c|c|}
\hline Penyebab & Penyebab & Akibat \\
\hline \multirow{8}{*}{$\begin{array}{l}\text { Mesin / } \\
\text { Lehr }\end{array}$} & $\begin{array}{l}\text { Penyetelan screen/sablon kurang } \\
\text { sesuai }\end{array}$ & Cat meleset \\
\hline & Penyetelan gambar tidak sesuai & $\begin{array}{l}\text { Under/Over } \\
\text { Label }\end{array}$ \\
\hline & $\begin{array}{l}\text { Cat yang keluar dari screen } \\
\text { kurang panas } \\
\text { Temperatur Decorating Lehr } \\
\text { kurang tinggi }\end{array}$ & Cat Kasar \\
\hline & $\begin{array}{l}\text { Stucker/pendorong botol tidak } \\
\text { bekerja sempurna }\end{array}$ & Lengket \\
\hline & $\begin{array}{l}\text { Temperatur Decorating Lehr } \\
\text { turun }\end{array}$ & Cat Mentah \\
\hline & $\begin{array}{l}\text { Temperatur Decorating Lehr } \\
\text { tidak sinkron shg penguapan } \\
\text { tidak teratur } \\
\text { Botol basah/mengembun } \\
\text { saat masuk oven }\end{array}$ & $\begin{array}{l}\text { Huruf tidak } \\
\text { teratur }\end{array}$ \\
\hline & $\begin{array}{l}\text { Temperatur Decorating Lehr } \\
\text { terlalu tinggi } \\
\text { Campuran Minyak yang } \\
\text { tidak sempurna }\end{array}$ & Cat Gosong \\
\hline & $\begin{array}{l}\text { Temperatur Slow Cooling di } \\
\text { Decorating Lehr tidak sesuai }\end{array}$ & Tegangan \\
\hline
\end{tabular}

\begin{tabular}{|l|l|l|}
\hline \multirow{5}{*}{} & Temperatur Screen tidak sesuai & Cat Blobor \\
\cline { 2 - 3 } & $\begin{array}{l}\text { Cat menetes saat proses } \\
\text { penuangan cat ke screen }\end{array}$ & Noda Cat \\
\cline { 2 - 3 } $\begin{array}{l}\text { Cat / } \\
\text { Screen }\end{array}$ & $\begin{array}{l}\text { Terdapat kotoran/debu pada } \\
\text { screen }\end{array}$ & $\begin{array}{l}\text { Cat } \\
\text { berlubang/ } \\
\text { gripis } \\
\end{array}$ \\
& $\begin{array}{l}\text { Huruf } \\
\text { hilang/ } \\
\text { putus }\end{array}$ \\
\cline { 2 - 3 } & Usia screen lama (perlu diganti) & Cat Tipis \\
\cline { 2 - 3 } & Cat gosong & $\begin{array}{l}\text { Warna tidak } \\
\text { cocok }\end{array}$ \\
\hline
\end{tabular}

\section{Proses Penyimpanan}

Kebanyakan botol yang selesai diproduksi berada di gudang dalam jangka waktu yang relatif singkat, hal ini disebabkan sistem produksi yang dianut oleh PT.Iglas adalah job order. Namun, perusahaan juga sesekali menimbun hasil produksinya manakala produksi melebihi dari jumlah yang seharusnya dikirimkan. Botol yang mengalami penimbunan dalam jangka waktu lebih dari tiga bulan sangat beresiko terjadi Weathering, yaitu kondisi botol yang menjadi buram akibat cuaca (botol kehujanan ataupun kepanasan). Di sini juga tidak terdapat record atau catatan mengenai berapa jumlah botol yang mengalami weathering. Bagian Pemasaran yang bertanggung jawab pada gudang akan meminta bagian Pengawasan Mutu (yang selanjutnya bagian pengawasan mutu akan meminta bagian laboratorium kimia) untuk memeriksa apakah terjadi weathering pada botol timbunan yang akan dikirim ke konsumen.

Weathering adalah suatu kondisi botol yang telah disimpan lebih dari tiga bulan sebagai stok gudang, di permukaan botol terdapat lapisan film tipis berupa silica gel. Uji dilakukan dengan memasukkan potongan botol dalam air dan membilasnya kemudian mentitrasi dengan $\mathrm{H}_{2} \mathrm{SO}_{4}$ $0.02 \mathrm{~N}$, mendidihkan dan mentitrasi dengan $\mathrm{NaOH}$ $0.02 \mathrm{~N}$. Selanjutnya dilakukan perhitungan jumlah mikrogram $/ \mathrm{cm}^{2}$ lapisan gel silica. Jumlah maksimal yang masih diijinkan adalah 2 mikrogram $/ \mathrm{cm}^{2}$.

Pada tahap ini dapat dikatakan tidak terlalu signifikan dalam mempengaruhi kualitas akhir dari suatu produk kemasan gelas yang sampai ke tangan konsumen karena adanya pengecekan tersebut. Namun, weathering tersebut dapat dikatakan suatu masalah kualitas yang perlu mendapat perhatian dari perusahaan.

\section{Proses Pengiriman}

Pengiriman yang dilakukan oleh pihak ketiga (perusahaan jasa transportasi) dapat dikatakan sangat sedikit mempengaruhi kualitas akhir 
produk. Selama ini masalah yang timbul selama proses pengiriman produk menuju Customer adalah adanya botol yang pecah akibat goncangan selama perjalanan. Hal tersebut dapat disebabkan kondisi jalan yang rusak dan berlubang sehingga timbul goncangan dalam kendaraan. Selama ini masalah tersebut dapat diatasi karena masih berada dalam batas toleransi perusahaan dan tidak sampai menimbulkan claim perusahaan kepada perusahaan jasa transportasi tersebut. Namun, dalam hal ini peneliti juga tidak mendapatkan data yang menunjukkan jumlah botol yang rusak akibat proses pengiriman. Bukti adanya masalah kualitas ini adalah adanya komplain bahwa botol yang dikirim roboh, selain kemasan yang kurang kencang, kondisi jalan juga memungkinkan terjadinya masalah ini.

Selain masalah kualitas yang dijabarkan di atas, job change juga perlu diperhatikan sebagai salah satu penyebab banyaknya cacat yang terjadi selama proses produksi. Job change adalah penggantian jenis botol yang akan diproduksi dengan mengganti cetakan botol. Adanya penggantian cetakan ini mesin dimatikan sehingga ketika awal produksi, mesin belum berjalan normal, terkadang terjadi kemacetan ataupun salah pengaturan. Namun, hal ini hanya berlangsung selama kurang lebih 5-10 menit pertama. Masalah lain yang terkadang timbul dan menyebabkan efisiensi hanya $0 \%$ adalah adanya botol warna tak homogen (WTH), listrik mati maupun peralatan mesin yang mengalami masalah sehingga mesin mati seluruhnya dan tidak dapat memproduksi.

Masalah kualitas pada PT.Iglas secara lengkap ditunjukkan pada gambar 5 .

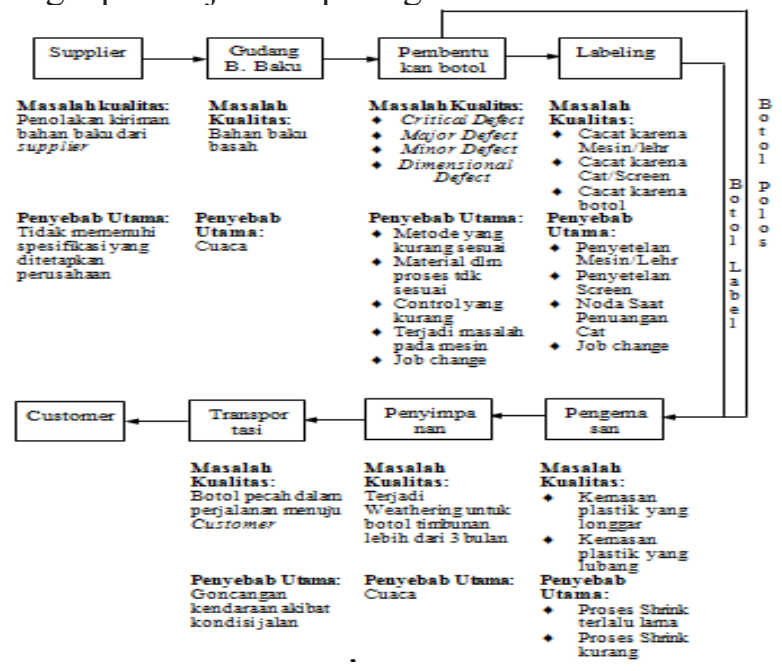

Gambar 5. Masalah kualitas pada supply chain kemasan gelas
Penerapan Manajemen Kualitas dan Upayaupaya Peningkatan Kualitas Kemasan Gelas

Dengan adanya masalah kualitas yang timbul pada beberapa tahap proses produksi maka diperlukan suatu peninjauan terhadap penerapan atau implementasi manajemen kualitas pada perusahaan dan upaya-upaya yang dilakukan perusahaan untuk mencegah dan meminimasi masalah kualitas yang timbul.

\section{Implementasi Manajemen Kualitas}

Dari pengumpulan data yang dilakukan melalui wawancara dan pengisian kuisioner oleh pihak yang berkompeten (dalam penelitian ini kuisioner diisi oleh Kepala Satuan Pengawas Intern (SPI), Wakil Komite Quality Management System \& ISO serta Manajer Product Desain) diperoleh data implementasi penerapan manajemen kualitas pada PT.Iglas, yang selanjutnya direkap dan dibuat grafik untuk menggambarkan dengan jelas manajemen kualitas yang diterapkan oleh perusahaan, ditunjukkan pada gambar 6 .

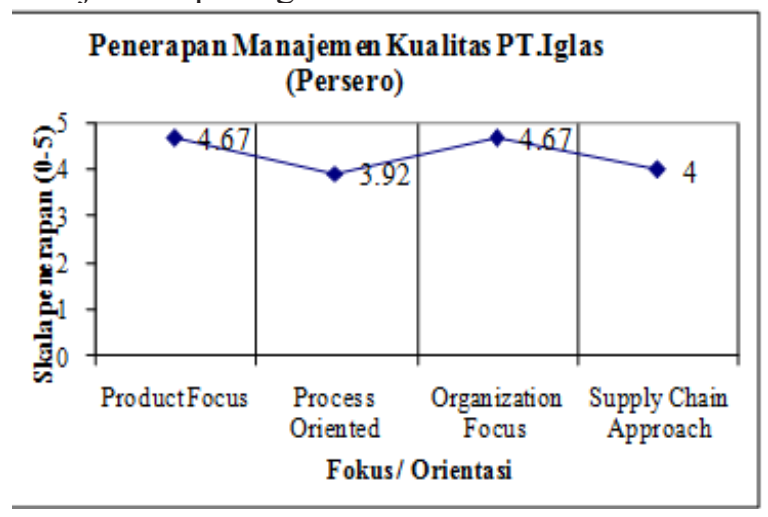

Gb. 6 Penerapan Manajemen Kualitas PT.Iglas

Dari grafik tersebut kita ketahui bahwa nilai tertinggi adalah 4.67 yaitu manajemen kualitas yang berfokus pada produk dan organisasi. Dari sini dapat disimpulkan bahwa fokus perusahaan masih sangat besar terhadap produk dan organisasi, jika dibandingkan dengan pendekatan mereka terhadap supply chain. Sedangkan orientasi pada prosesnya masih dapat dikatakan cukup rendah. Dengan demikian dapat disimpulkan bahwa praktek manajemen kualitasnya reaktif terhadap permasalahan yang muncul dan memandang kualitas sebagai outcome dari upaya organisasi secara keseluruhan (strategis) selain itu juga cukup kolaboratif, melibatkan pihak di luar organisasi untuk menciptakan kualitas lintas perusahaan sebagai upaya untuk menciptakan pelayanan 
yang tinggi bagi pelanggan akhir. Namun, kurang preventif atau kurang melakukan pengendalian proses dalam menciptakan kualitas.

\section{Product Focus (Reaktif)}

Dari lima pertanyaan yang diajukan untuk mengetahui apakah perusahaan menerapkan manajemen kualitas yang berfokus pada produk didapatkan nilai rata-rata 4.67 (skala 5) yang berarti fokus perusahaan terhadap produk sangat tinggi. Pertanyaan-pertanyaan untuk menilai tersebut adalah

Pertanyaan 1. "Kami melakukan incoming inspection dengan sangat ketat bagi barangbarang yang diterima dari supplier." Dari ketiga responden semua menjawab sama yaitu 5 (lima) artinya mereka memiliki persamaan pendapat tentang hal ini. Dibuktikan dengan adanya pemeriksaan oleh bagian Laboratorium Kimia pada setiap kiriman bahan baku yang datang dari supplier. Bahan baku yang tidak sesuai dengan standart akan ditolak.

Pertanyaan 2. "Bagi kami, kualitas sangat dipengaruhi oleh kemampuan supplier maupun produksi memenuhi spesifikasi teknis." Untuk hal ini pun terdapat persamaan pandangan oleh ketiga responden yaitu nilai 5 (lima) yang berarti mereka masih menganggap bahwa kualitas produk "sangat" dipengaruhi oleh bahan baku dan proses produksi, hal-hal lain dianggap kurang mempengaruhi kualitas produk.

Pertanyaan 3. "Inspeksi produk setengah jadi maupun produk jadi cukup ketat". Untuk pertanyaan ini terdapat range sebesar 1 (satu) dengan rata-rata 4.67, hal ini juga berdasarkan kenyataan bahwa inspeksi yang dilakukan tidak hanya pada satu tempat tetapi beberapa tempat antara lain saat botol baru saja keluar dari mesin pencetak botol, di bagian sortir, botol juga mengalami penyamplingan oleh bagian pengawasan mutu, setelah selesai proses ACL (untuk botol dengan label) dan terakhir secara sekilas saat botol hendak dikirim ke konsumen.

Pertanyaan 4. "Kualitas produk sangattergantung pada para inspektor (yang melakukan inspeksi/ pengecekan kualitas)." Untuk pertanyaan ini juga terdapat range sebesar 1 (satu) dengan ratarata 4.67 , hal ini juga berdasarkan kenyataan bahwa banyak botol yang lolos ke konsumen akibat inspektor yang kurang teliti dalam menyortir botol-botol yang cacat.
Pertanyaan 5. "Kami merasa bagian yang paling dominan dalam menciptakan kualitas adalah bagian produksi." Para responden menjawab sama yaitu nilai 4 (empat) karena mereka menganggap kualitas produk secara dominan diciptakan oleh bagian produksi tetapi tidak seutuhnya diciptakan oleh bagian ini, ada hal lain yang ikut berperan.

\section{Process Oriented (Preventif)}

Dari empat pertanyaan yang diajukan untuk mengetahui apakah perusahaan menerapkan manajemen kualitas yang berorientasi pada proses didapatkan nilai rata-rata 3.92 (skala 5) yang berarti orientasi perusahaan terhadap proses lebih rendah jika dibandingkan dengan fokus perusahaan terhadap produk. Pembahasan untuk pertanyaanpertanyaan tersebut adalah

Pertanyaan 1. "Kami menerapkan SPC (statistical process control)." Untuk pertanyaan ini terdapat range sebesar 1 (satu) dengan ratarata 4.33. Hal ini disebabkan SPC digunakan tetapi tidak begitu sering.

Pertanyaan 2. "Bagi perusahaan kami, membuang produk cacat jauh lebih mahal dibandingkan mencegah terjadinya cacat." Untuk pertanyaan ini terdapat range yang cukup besar yaitu 3 (tiga) dengan nilai terendah 2 (dua) dan nilai tertinggi 5 (lima), adanya range ini menandakan adanya perbedaan persepsi antara manajemen dalam memandang cacat. Bagi responden yang menjawab 2 berarti tidak setuju dengan pernyataan di atas, baginya lebih baik membuang produk yang cacat daripada mencegahnya sedangkan yang menjawab 5 berarti sebaliknya. Dianggap lebih baik membuang karena botol yang cacat dapat didaur ulang sebagai bahan baku (cullet) sedangkan yang menganggap lebih baik mencegah, hal ini disebabkan adanya pandangan mencegah cacat (meskipun mahal) sebagai investasi jangka panjang.

Pertanyaan 3. "Kami menggunakan alat-alat seperti pareto, fish bone diagram, dll untuk melacak penyebab terjadinya masalah kualitas." Untuk pertanyaan ini terdapat range sebesar 1 (satu) dengan rata-rata 3.67. Iglas selalu mencari penyebab cacat yang timbul tetapi tidak selalu menggunakan alat-alat tersebut, kebanyakan melalui analisa yang kemudian dipaparkan ke semua unit terkait dalam rapat kualitas untuk 
segera ditindaklanjuti.

Pertanyaan 4. "Aplikasi alat-alat kualitas juga dilakukan untuk proses-proses di luar lantai produksi (mis. Gudang, pengiriman barang, dll.)" Untuk pertanyaan ini semua responden sepakat menjawab 4 (empat) atau dengan kata lain setuju dengan pernyataan tersebut, alat kualitas yang hampir selalu ada adalah Check Sheet yang digunakan sebagai alat untuk pengumpulan data, misal adanya data persediaan di gudang.

\section{Organization Focus (Strategis)}

Dari empat pertanyaan yang diajukan untuk mengetahui apakah perusahaan menerapkan manajemen kualitas yang berorientasi pada proses didapatkan nilai rata-rata 4.67 (skala 5) yang berarti fokus perusahaan terhadap organisasi sama dengan fokus perusahaan terhadap produk. Pembahasan untuk pertanyaan-pertanyaan tersebut adalah

Pertanyaan 1. "Perusahaan melibatkan semua karyawan (tidak hanya yang di bagian produksi) dalam program-program kualitas." Untuk pertanyaan ini semua responden sepakat menjawab 5 artinya sangat setuju dengan pernyataan di atas, hal ini dibuktikan dengan adanya rapat kualitas yang anggotanya adalah Cross Functional.

Pertanyaan 2. "Saran-saran dari karyawan sangat diperhatikan dalam meningkatkan kualitas." Untuk pertanyaan ini terdapat range sebesar 1 (satu) dengan rata-rata 4.33, Iglas memang melibatkan karyawannya dalam meningkatkan kualitas, tetapi tidak semuanya, forum yang secara kontinue ada untuk membahas masalah kualitas adalah rapat kualitas.

Pertanyaan 3. "Manajemen puncak punya komitmen yang tinggi dalam menerapkan manajemen kualitas di semua lini organisasi." Untuk pertanyaan ini terdapat range sebesar 1 (satu) dengan rata-rata yang cukup besar yaitu 4.67. Hal ini dibuktikan dengan dibentuknya Komite Quality Management System dan ISO yang fungsi utamanya mengawasi jalannya sistem agar sesuai dengan kesepakatan bersama.

Pertanyaan 4. "Bagi manajemen, kualitas tidak hanya berarti produk yang berkualitas, tetapi juga sistem yang berjalan sesuai prosedur." Untuk pertanyaan ini juga terdapat range sebesar 1 (satu) dengan rata-rata yang cukup besar yaitu 4.67. Komite Quality Management System dan ISO fungsi utamanya mengawasi jalannya sistem agar sesuai dengan yang disepakati juga merupakan suatu bukti bahwa perusahaan juga berkeinginan sistemnya dapat berjalan sesuai prosedur.

\section{Supply Chain Approach (Kolaboratif)}

Dari tujuh pertanyaan yang diajukan untuk mengetahui apakah perusahaan menerapkan manajemen kualitas yang pendekatannya pada supply chain didapatkan nilai rata-rata 4.00 (skala 5) yang berarti pendekatan prusahaan terhadap supply chain cukup tinggi namun masih kalah jika dibandingkan dengan fokus perusahaan terhadap organisasi dan terhadap produk. Pembahasan untuk pertanyaan-pertanyaan tersebut adalah

Pertanyaan 1. "Kami melibatkan pelanggan dalam menjaring Voice of Customers (end customers)." Untuk pertanyaan ini terdapat range sebesar 1 (satu) dengan rata-rata 4.33. Cara yang digunakan untuk menjarig voice of Customer antara lain melalui kunjungan yang dilakukan oleh kedua belah pihak dan melalui bagian Customer Relationship yang berada di bawah Departemen Pengembangan Bisnis.

Pertanyaan 2. "Perusahaan memiliki program pelatihan kualitas bersama supplier atau pelanggan." Jawaban yang diberikan memiliki rata-rata 3.67 dengan range 1 . Perusahaan memang pernah melakukan pelatihan dengan partnernya namun hal tesebut jarang terjadi.

Pertanyaan 3. "Kami melakukan joint improvement bersama buyer / supplier (formal maupun tidak formal)." Jawaban yang diberikan memiliki rata-rata 3.67 dengan range 1. Joint improvement dengan supplter dilakukan dengan jalan menginformasikan spesifikasi bahan baku kepada supplier, sedangkan dengan konsumen dilakukan dengan kunjungan dua belah pihak.

Pertanyaan 4. "Kami melakukan pembinaan kualitas ke supplier." Jawaban yang diberikan memiliki rata-rata 4.00 dengan range 2 . Range tersebut cukup besar mengingat seharusnya ketiga responden memiliki pendapat yang sama didasarkan pada kenyataan yang terjadi di perusahaan. Hal ini terjadi karena adanya kekurangtahuan tentang aktivitas ini. Dari kunjungan ke salah satu supplier lokalnya didapatkan informasi bahwa Iglas tidak pernah memberikan pembinaan, hanya menginformasikan spesifikasi bahan baku yang 
diminta.

Pertanyaan 5. "Kami memiliki informasi yang transparan tentang masalah-masalah kualitas di channel lain pada supply chain". Untuk pertanyaan ini semua responden sepakat menjawab 4 (empat) atau dengan kata lain setuju dengan pernyataan tersebut, bahwa informasi yang ada pada setiap channel supply chain memiliki informasi yang transparan dan ada pembahasan untuk setiap masalah yang terjadi pada channel supply chain tersebut.

Pertanyaan 6. "Kami melibatkan supplier dalam perancangan produk baru". Pertanyaan ini memiliki range yang besar yaitu tiga (3) dengan rata-rata 3.67 , hal ini juga dimungkinkan berdasarkan kekurangtahuan dari responden. Dari hasil wawancara yang dilakukan, supplier dipilih dengan sistem pelelangan, jadi berdasarkan apa yang diminta oleh perusahaan.

Pertanyaan 7. "Perusahaan bersama supplier dan buyer melakukan continuous improvement". Untuk pertanyaan ini range yang dihasilkan sebesar 1, dengan rata-rata 4.67. Perusahaan memang melakukan continuous improvement, tetapi berdasarkan pengetahuan peneliti kebanyakan program tersebut lebih banyak melibatkan buyer daripada supplier.

\section{Upaya-upaya Perusahaan}

Selain melihat penerapan atau implementasi manajemen kualitasnya perlu juga dilihat upayaupaya yang selama ini dilakukan oleh perusahaan.

\section{- Training Pegawai/Karyawan}

Dari 97 training dan pelatihan yang dilakukan perusahaan dalam kurun waktu Januari-September 2005 ada kurang lebih 10 (sepuluh) pelatihan atau training yang berhubungan dengan manajemen kualitas yang diterapkan perusahaan. Jumlah tersebut peneliti rasa masih sangat sedikit karena hanya sekitar $10.31 \%$ dari total pelatihan yang diadakan. Perusahaan hendaknya lebih memperbanyak pelatihan yang berhubungan dengan manajemen kualitas sehingga semakin banyak karyawan ataupun pegawai yang memahami manajemen kualitas yang diterapkan perusahaan.

\section{- Pembentukan Komite Quality Mnagement System \& ISO}

Komite Quality Management System \& ISO merupakan struktur baru di dalam struktur 20 organisasi PT.Iglas (Persero). Fungsi dan tugas dari komite ini adalah melakukan pengendalian terhadap sistem manajemen yang diterapkan di PT.Iglas (Persero) yaitu sistem manajemen ISO 9001:2000 yang merupakan penyempurnaan dari sistem manajemen ISO 9002. Sistem manajemen ini diterapkan untuk menjamin kualitas dari produk yang dihasilkan oleh PT.Iglas.

Di dalam sistem PT.Iglas ini diberlakukan dua jenis audit yaitu internal audit dan eksternal audit. Internal audit dilakukan untuk melihat apakah sistem yang telah disepakati dapat dilaksanakan. Internal audit dilakukan oleh pejabat eselon1 dan eselon2 yang telah memperoleh training auditor. Sedangkan eksternal audit dipercayakan kepada TUUF, Jerman.

Program kerja yang dilaksanakan oleh komite ini adalah Continual Improvement Program yang berisi perbaikan-perbaikan dari masing-masing departemen secara terus-menerus, misalnya menemukan hal-hal baru atau melakukan upgreeding terhadap sesuatu yang lama. Masingmasing departemen menggunakan siklus PDCA yang pelaksanaannya diawasi dan diuji oleh komite ini.

\section{- Rapat Kualitas Pagi}

Rapat kualitas Pagi adalah salah satu program intern perusahaan yang dilakukan setiap pagi jam 09.00 waktu setempat. Tujuan diadakannya rapat ini adalah untuk mengevaluasi hasil produksi pada hari sebelumnya dan membahas cacat-cacat botol yang terjadi pada pagi hari sebelum rapat tersebut dilaksanakan. Untuk selanjutnya dilakukan perumusan langkah-langkah atau tindakan yang akan dilakukan untuk mengatasi masalah tersebut dan penentuan orang yang menjadi penanggung jawab terhadap pelaksanaan tindakan perbaikan tersebut.

Anggota dari rapat kualitas ini adalah dari berbagai fungsi dalam perusahaan atau dapat disebut sebagai cross functional, yaitu:

- Kepala Departemen Teknik

- Kepala Seksi Forming

- Kepala Seksi Pencampuran dan Peleburan Bahan (PPB)

- Kepala Seksi Sortir

- Kepala Seksi Pembangkit Tenaga

- Kepala Seksi Perawatan Umum Pabrik (PUP)

- Kepala Seksi Mesin AIS

- Kepala Seksi Pengawasan Mutu 
- Kepala Seksi Listrik

- Kepala Regu Bengkel cetakan

bertindak sebagai pimpinan rapat adalah Kepala Seksi Forming, karena dianggap sebagai orang yang paling mengerti terhadap penyebab timbulnya cacat botol, sedangkan notulennya adalah Kepala Seksi Pengawasan Mutu, selain sebagai penanggung jawab terhadap kualitas botol yang dihasilkan, bagian ini juga sebagai tuan rumah pelaksanaan rapat kualitas. Tindak lanjut dari Rapat kualitas Pagi adalah rapat siang dan rapat malam yang dilakukan oleh shift yang bertugas pada saat itu.

\section{- Program Kerjasama dengan Customer}

Dari kunjungan yang dilakukan ke PT. Coca Cola Bottling Indonesia, yang selanjutnya disingkat PT.CCBI, Jawa Timur sebagai salah satu Customer terbesar PT.Iglas didapatkan keterangan bahwa selama ini dapat dikatakan 99,99\% botol yang dikirimkan oleh PT.Iglas dalam kondisi baik. Konsumen juga tidak akan menerima botol yang datang jika tidak disertai adanya Certificate of Quality Analysis dari perusahaan. Meskipun demikian pihak konsumen tetap melakukan incoming inspection.

Karakteristik kualitas botol yang penting bagi PT.CCBI dan menjadikan PT.CCBI percaya kepada PT.Iglas sebagai salah satu (dari 2) supplier botolnya adalah:

1. Harga lebih murah dan relatif stabil terhadap beberapa perubahan, misalnya kenaikan BBM. Hal ini disebabkan kerja sama yang dianut kedua belah pihak adalah sistem kontrak selama 5 tahun.

2. Kualitas produk yang dihasilkan sesuai standart dan lebih murah.

Meskipun pengorderan dilakukan melalui PT.Coca Cola Indonesia (PT.CCI) yang berada di Jakarta, Iglas juga menjalin kerjasama dengan PT.CCBI antara lain:

- Secara formal, melalui:

1. Kunjungan kedua belah pihak, walaupun tidak terjadi komplain, pihak Iglas dalam jangka waktu tertentu akan melakukan kunjugan untuk mendengarkan masalah atau keluhan yang terjadi pada konsumennya sebagai wujud dari kepedulian PT.Iglas agar konsumennya loyal, demikian pula sebaliknya Coca Cola juga dalam jangka waktu tertentu akan melakukan kunjungan ke PT.Iglas untuk saling bertukar informasi.

2. Audit yang dilakukan oleh PT. CCI

Audit yang dimaksud dilakukan untuk meyakinkan Coca Cola bahwa PT.Iglas masih layak menjadi produsen dari kemasan botol yang selama ini digunakan oleh Coca Cola.

- Secara tidak formal, program kerjasama secara tidak formal antara lain dilakukan oleh tingkat officer melalui olah raga, dalam kesempatan tersebut digunakan pula untuk membicarakan permasalahan kualitas yang dihadapi kedua belah pihak.

Untuk tingkatan penerapan manajemen kualitas oleh customernya maka digunakan kuisioner penerapan manajemen kualitas yang dalam hal ini pengisiannya dilakukan oleh Incoming Material \& Lab. Support Supervisor, Full Good \& Empty Reporting dan Delivery Requirement Planning Supervisor. Hasilnya dapat dilihat pada gambar 7, dimana dapat diketahui bahwa penerapan manajemen PT.CCBI lebih berfokus pada organisasi artinya lebih bersifat strategis atau memandang kualitas sebagai outcome dari upaya organisasi secara keseluruhan, tetapi dapat dlilihat pula bahwa pendekatan terhadap supply chain mendapat prioritas paling rendah, jadi sikap kolaboratifnya masih kurang.

\section{- Program Kerjasama dengan Supplier}

PT.Iglas juga melakukan program pembinaan dengan para suppliernya tetapi tidak ke semuanya. Supplier-supplier dari luar negeri rata-rata mereka telah memiliki sertifikasi yang menyatakan bahwa produk yang diproduksinya telah memenuhi standar kualitas, sehingga Iglas merasa tidak perlu lagi melakukan pembinaan. Pembinaan hanya diperuntukkan bagi supplier-supplier tingkat kecil dan memang dirasa perlu untuk dilakukan pembinaan. Namun, dari hasil kunjungan ke salah satu supplier yang dapat dikatakan masih berskala kecil (CV), mereka mengatakan bahwa selama ini pihak Iglas hampir tidak pernah datang untuk melakukan pembinaan, mereka hanya menyebutkan spesifikasi yang diminta melalui surat pesanan. Disini terjadi perbedaan pendapat antara pihak supplier dengan pihak Iglas, peneliti dapat menyimpulkan bahwa apa yang dikatakan pembinaan oleh Iglas adalah pemberitahuan spesifikasi tersebut kepada supplier, tetapi tidak 
ada program yang digunakan untuk memberikan pengarahan pada supplier bagaimana mencapai target spesifikasi tersebut.

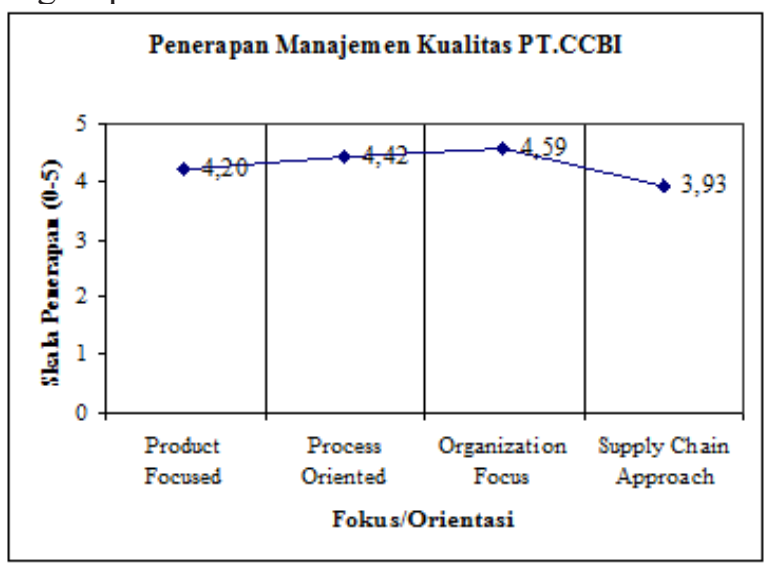

Gambar 7. Penerapan Manajemen Kualitas PT. CCBI

\section{Usulan Perbaikan}

Dalam usaha meningkatkan kualitas dari kemasan gelas dan mengurangi jumlah cacat yang terjadi maka peneliti berusaha memberikan usulan perbaikan guna mencapai tujuan tersebut. Dari perumusan usulan perbaikan yang diberikan selanjutnya diperkirakan manfaat yang ditimbulkan jika usulan perbaikan tersebut dilakukan. Usulan perbaikan dan perkiraan manfaat yang ditimbulkan selanjutnya ditunjukkan pada tabel 10 .

\section{KESIMPULAN}

Dari hasil penelitian terhadap permasalahan kualitas di PT.Iglas (Persero) Surabaya dapat ditarik beberapa kesimpulan :

1. Permasalahan kualitas tidak hanya terjadi pada proses produksi tetapi juga terjadi pada bahan baku yang dikirimkan oleh supplier, proses pelabelan (ACL), pengemasan, penyimpanan dan pengiriman.

2. Permasalahan yang hampir setiap saat terjadi dengan frekuensi tinggi adalah proses produksi (forming) dan pelabelan (ACL). Cacat yang terjadi pada proses forming dikategorikan menjadi critical defect, major defect, minor defect dan dimensional defect. Sedangkan cacat pada proses pelabelan disebabkan oleh mesin/lehr, cat/screen dan botol yang lolos dari penyortiran.

3. Perusahaan tidak memberikan informasi secara terperinci tentang penyebab kiriman dipotong dengan suatu jumlah tertentu sehingga supplier sering melakukan kesalahan yang sama.

4. Hampir seluruh cacat yang terjadi baik dari 22 proses forming maupun ACL tidak luput dari faktor salah set-up mesin yang kurang sesuai oleh manusia, sehingga perlu dilakukan pelatihan yang lebih intensif.

5. Perusahaan memiliki program kerjasama dengan customer melalui kunjungan kedua belah pihak dan audit serta program kerjasama dengan supplier yang berskala kecil dan dirasa memerlukan pembinaan. Namun kenyataan di lapangan salah satu supplier mengatakan bahwa Iglas hanya menginformasikan spesifikasi yang diminta.

6. Dalam praktek manajemen kualitasnya PT.Iglas lebih bersifat reaktif dalam menghadapi permasalahan dan strategis, dalam arti melibatkan seluruh anggota organisasi dalam menciptakan kualitas. Namun, perusahaan kurang bersifat preventif atau kurang melakukan pengendalian proses. Dari segi sifat kolaboratif juga masih kurang, sehingga perlu ditingkatkan kerjasama dengan anggota supply chain lain.

7. Inti dari perbaikan yang dapat diusulkan untuk perusahaan adalah pelatihan bagi karyawan dan pengawasan proses yang lebih intensif, karena hampir semua cacat yang terjadi tidak lepas dari kesalahan karyawan dalam melakukan pekerjaannya, seperti set-up mesin.

\section{DAFTAR PUSTAKA}

Besterfield, D.H, Michna, C.B., Besterfield, G.H., Sacre, M.B., (1995), Total Quality Management, Prentice Hall, New Jersey

Chopra, S and Meindl, P, (2004), Supply Chain Management : Strategy, planning, and operation, Prentice hall, New Jersey

Fitria, L dan Indah, N., (2005), Supply Chain PT.Iglas (Persero), Laporan Kerja Praktek, ITS Surabaya

Gaspresz, Vincent (2002). Pedoman Implementasi Program Six Sigma Terintegrasi dengan ISO 9001: 2000, MBNQA, dan HCCP, PT. Gramedia Pustaka Umum, Jakarta.

Gitlow, H.,Oppeinheim, A., Oppeinheim, R., (1995), Quality Management : Tools and Methods for improvement, Richard D. Irwin, USA

Gunawan, A., (2005), Pendekatan Six Sigma untuk Mengurangi Jumlah Cacat Kritis pada Produk Botol Fanta Splash Ultra di PT.Iglas (Persero) Gresik, Tugas Akhir, ITS Surabaya

Mehra, S., Hoffman, J.M., Danilo, S., (2001), Total 
Quality management as a Management strategy for the next millennia, International Journal of Operation and production Management 21: $855-876$

Montgomary, C. Douglas (1995), Pengantar Pengendalian Kualitas Statistik, Gadjah Mada University Press, Yogyakarta

Novianti, Y., (2005), Mengurangi Defect pada Hasil Produksi dengan Mengevaluasi Sistem Produksi dan Pasokan Bahan Baku (Studi Kasus : PT. Pabrik Gula Krebet Batu Malang). Tugas akhir, ITS Surabaya.
Puspitasari, R., (2005), Evaluasi Defect dan Lead Time pada Supply Chain Produk lampu pijar (GLS). Tugas akhir, ITS Surabaya.

Robinson, J.C and Maholtra, M.K (2004) Defining The Concept of Supply Chain Quality Management and Its Relevant to Academeic and Industrial Practice, Columbia ( http // www.elsevier .com )

Ross, D.F., (1997), Competing Through Supply Chain management - Creating Market - Winning strategies through Supply Chain Partnership, Chapman and hall, New York.

Tabel 10. Usulan Perbaikan dan Perkiraan Manfaat

\begin{tabular}{|c|c|c|}
\hline Alasan & Usulan & Perkiraan manfaat \\
\hline \multirow{3}{*}{$\begin{array}{l}\text { Hampir tiap bulan ada } \\
\text { potongan untuk bahan baku } \\
\text { beling yang dikirimkan oleh } \\
\text { supplier }\end{array}$} & $\begin{array}{l}\text { Hasil pemeriksaan Laboratorium Kimia } \\
\text { diinformasikan secara terperinci kepada } \\
\text { supplier }\end{array}$ & \multirow{3}{*}{$\begin{array}{l}\text { - Supplier jelas penyebab kirimannya } \\
\text { dipotong sehingga berusaha menghindari } \\
\text { kesalahan yang sama untuk pengiriman } \\
\text { mendatang. } \\
\text { - Mengurangi biaya, waktu dan tenaga } \\
\text { untuk incoming inspection }\end{array}$} \\
\hline & $\begin{array}{l}\text { Pembinaan kepada supplier tentang cara } \\
\text { pemilahan beling }\end{array}$ & \\
\hline & $\begin{array}{l}\text { Adanya tindakan tegas untuk memberikan } \\
\text { sanksi bagi supplier yang berulang kali } \\
\text { pengirimannya tidak sesuai dengan } \\
\text { spesifikasi }\end{array}$ & \\
\hline $\begin{array}{l}\text { Banyak botol cacat yang lolos } \\
\text { ke konsumen }\end{array}$ & Menambah jumlah tenaga sortir & $\begin{array}{l}\text { Cacat yang tidak terdeteksi oleh seorang } \\
\text { penyortir masih memiliki kemungkinan } \\
\text { terdeteksi.oleh penyortir berikutnya }\end{array}$ \\
\hline \multirow{5}{*}{$\begin{array}{l}\text { Cacat proses forming maupun } \\
\text { ACL hampir setiap saat terjadi }\end{array}$} & $\begin{array}{l}\text { Meningkatkan jumlah sampling } \\
\text { Menambah jumlah pelatihan bagi operator } \\
\text { mesin }\end{array}$ & $\begin{array}{l}\text { Kemungkinan botollolos semakin kecil } \\
\text { Lebih tanggap untuk mengubah set-up } \\
\text { mesin ketika terjadi botol cacat }\end{array}$ \\
\hline & $\begin{array}{l}\text { Peningkatan kegiatan pengontrolan dan } \\
\text { pengawasan }\end{array}$ & $\begin{array}{l}\text { Cacat yang keluar dari mesin sesegera } \\
\text { mungkin dapat terdeteksi sehingga cacat } \\
\text { dapat segera dihentikan }\end{array}$ \\
\hline & Pengecekan parameter mesin secara berkala & Menghindari kerusakan dan salah \\
\hline & Penggantian cetakan sesuai waktu (berkala) & $\begin{array}{l}\text { Menghindari cacat yang disebabkan oleh } \\
\text { cetakan yang sudah tidak sesuai }\end{array}$ \\
\hline & Pengecekan suhu secara teratur & $\begin{array}{l}\text { Meminimasi jumlah cacat yang kebanyakan } \\
\text { disebabkan adanya temperatur yang tidak }\end{array}$ \\
\hline $\begin{array}{l}\text { Terjadi weathering pada botol } \\
\text { timbunan terutama yang } \\
\text { disimpan di halaman pabrik }\end{array}$ & $\begin{array}{l}\text { Menyediakan gudang (tempat penyimpanan } \\
\text { botol) dengan kondisi terlindung dari sinar } \\
\text { matahari dan hujan }\end{array}$ & $\begin{array}{l}\text { Kemungkinan terjadi weathering dapat } \\
\text { diperkecil. }\end{array}$ \\
\hline Kemasan dari plastik berlubang & $\begin{array}{l}\text { Memperkecil api yang digunakan untuk } \\
\text { proses shrink }\end{array}$ & $\begin{array}{l}\text { Kemasan plastik tidak mudah berlubang } \\
\text { akibat proses shrink }\end{array}$ \\
\hline Kemasan plastik kendor & Menambah waktu untuk proses shrink & Kemasan plastik lebih kencang namun tidak \\
\hline $\begin{array}{l}\text { Botol roboh/pecah selama } \\
\text { pengiriman }\end{array}$ & $\begin{array}{l}\text { Menambah ikatan yang kencang pada } \\
\text { kemasan botol maupun pada kendaraan } \\
\text { pengangkut }\end{array}$ & $\begin{array}{l}\text { Botol tidak memiliki kesempatan untuk } \\
\text { bergeser dari tempatnya. }\end{array}$ \\
\hline $\begin{array}{l}\text { Manajemen Kualitas yang } \\
\text { diterapkan kurang bersifat } \\
\text { preventif }\end{array}$ & $\begin{array}{l}\text { Melakukan pengendalian proses secara } \\
\text { berkelanjutan }\end{array}$ & $\begin{array}{l}\text { Dengan proses yang terkendali, jumlah cacat } \\
\text { dapat diminimalisasi }\end{array}$ \\
\hline $\begin{array}{l}\text { Banyak botol cacat akibat job } \\
\text { change }\end{array}$ & $\begin{array}{l}\text { Mengoven cetakan sampai dapat dipastikan } \\
\text { bahwa temperatur cetakan sudah sesuai } \\
\text { untuk produksi }\end{array}$ & $\begin{array}{l}\text { Mengurangi cacat yang banyak terjadi pada } \\
\text { saat job change yang disebabkan cetakan } \\
\text { masih dingin, seperti cold mould. }\end{array}$ \\
\hline
\end{tabular}

